\title{
Palatability of Meat from Chickens Raised on Diets Containing Different Levels of Tuna and Meat Meals. Evaluation by a Trained Panel ${ }^{1}$
}

\author{
Manuel Soldevila, Lilia Lefebre González, and Juan A. Morassi² \\ INTRODUCTION
}

Considerable amounts of tuna fish meal and moderate amounts of meat meal with bone are produced in Puerto Rico. These ingredients are less expensive per protein unit and more readily available than imported soybean meal. Diets containing high levels of both locally produced ingredients have been formulated and evaluated $(8)^{3}$ in an effort to lower feed costs.

The objective of the studies reported herein was to determine if meat from poultry raised on diets containing different levels of tuna fish and meat meals have undesirable off flavors or odors as determined by a trained panel.

\section{REVIEW OF THE LITERATURE}

A search of the literature revealed no reports available describing the maximum level of tuna fishmeal that may be used in practical diets without adversely affecting the palatability of the meat of poultry fed them. Carlson et al. (1), Dansky (2), Edwards and May (3), and Hardin et al. (5) reported that the off flavor, caused when fishmeals other than tuna were used, was due to their fat fraction. Sala and Chiarella (11) reported that anchovy fish oil in excess of 1.4 percent of the diet caused a fishy flavor in poultry meat. Hardin (5) reported that a level of 1.8 percent of anchovy oil was offensive. Carlson et al. (1) reported 1.0 percent of menhaden fish oil as distasteful, while Dansky (2), and Edwards and May (S) reported 2.0 percent as marginal, and 3.0 percent as unsavory. Leong et al. (7) reported that the unsaturated fatty acids present in fishmeals cause the off flavor. Fry et al. (4) reported no fishy or off flavor in poultry meat when anchovy and menhaden fishmeals were used as the sole protein sources in a diet.

\section{MATERIAL AND METHODS}

A trained taste panel conducted five different flavor and odor evaluations of drumstick meat from chickens representative of diets containing dif-

1 Some of the data reported herein was part of a thesis submitted by J. A. Morassi in partial fulfillment of the requirements for the M.S. degree, Department of Animal Industries, Mayagüez Campus, University of Puerto Rico.

${ }^{2}$ Associate Nutritionist and Associate Professor, Department of Animal Husbandry; Assistant Food Technologist, Food Technology Laboratory, Agricultural Experiment Station; and former graduate student of Animal Industries, Mayagüez Campus, University of Puerto Rico (present address: Asunción, Paraguay).

${ }^{8}$ Italic numbers in parentheses refer to Literature Cited, pp. 55-6. 
ferent combinations of tuna, meat, and soybean meal used in three nutritional comparative studies (table 1).

Study I consisted of Evaluations A and B. Evaluation A (table 1) consisted of tasting "drumsticks" from chickens raised on diets 1 (24-percent soybean), 2 (24-percent tuna) and 3 (12-percent soybean + 12-percent tuna). Evaluation B (table 1) was conducted 2 weeks after evaluation A, on "drumsticks" from chickens receiving diets 4 (12-percent meàt + 12percent tuna), 5 (24-percent meat) and 6 (12-percent meat + 12-percent soybean). Birds started this study at 6 weeks of age, weighing over $680 \mathrm{~g}$. They were randomized into the six treatments and fed the experimental diets to the eighth week of age. These birds had been fed the same combina-

TABLE 1.-Panel evalualion of meat from chickens fed diets containing different combinations of tuna, meat, and soybean meals in study $I^{1}$

\begin{tabular}{|c|c|c|c|c|c|c|}
\hline \multirow[b]{2}{*}{ Score } & \multicolumn{3}{|c|}{ Evaluation A2, 8 } & \multicolumn{3}{|c|}{ Evaluation $\mathbf{B}^{\mathbf{c}, \mathrm{B}}$} \\
\hline & $\begin{array}{c}\text { Diet 1 } \\
\text { (24-percent } \\
\text { soybean) }\end{array}$ & $\begin{array}{c}\text { Diet 2 } \\
\text { (24-percent } \\
\text { tuna) }\end{array}$ & $\begin{array}{c}\text { Diet } 3 \\
\text { (12-percent } \\
\text { soybenn }+12- \\
\text { percent tuna })\end{array}$ & $\begin{array}{c}\text { Diet 4 } \\
\text { (12-percent } \\
\text { meat + 12-per- } \\
\text { cent tuns) }\end{array}$ & $\begin{array}{c}\text { Diet 5 } \\
\text { (24-percent } \\
\text { meat) }\end{array}$ & $\begin{array}{c}\text { Diet 6. } \\
\text { (12-percent } \\
\text { meat + 11-per- } \\
\text { cent soybean) }\end{array}$ \\
\hline $\begin{array}{l}\text { Total } \\
\text { Average }\end{array}$ & $\begin{array}{r}14.0 \\
+0.8\end{array}$ & $\begin{array}{r}19.5 \\
+1.2\end{array}$ & $\begin{array}{r}13.5 \\
+0.8\end{array}$ & $\begin{array}{r}11.0 \\
+0.6\end{array}$ & $\begin{array}{r}14.0 \\
+0.8\end{array}$ & $\begin{array}{r}18.0 \\
+1.0\end{array}$ \\
\hline
\end{tabular}

1 The scale used was as follows: Very acceptable +2 ; acceptable +1 ; questionable 0 ; slightly unacceptable -1 ; not acceptable -2 .

2 Evaluation A conducted January 27, 1966.

Range $(n=16)$ among totals for difference at $\mathrm{P}<.05=13.0$ (N.S.).

- Evaluation B conducted February 8, 1966.

5 Range $(n=18)$ among totals for difference at $P<.05=10.6$ (N.S.).

tions of protein sources as evaluated in this period during their first 6 weeks of age.

Study II consisted of evaluations $C$ and $D$, in which the meat from birds receiving four of the diets previously studied in evaluations $A$ and $B$. were simultaneously evaluated by a trained taste panel (table 2). In contrast with the first study, day-old chicks were sorted randomly and all received the same diet of 15 percent each of fishmeal and soybean meal during the starting period (0-6th week of age). During the fattening period the birds received diets $1,2,3$, and 4 . Treatments 5 and 6 were eliminated because the growth performance of the birds receiving them was not as good as those of the other four diets. This also was true for diet 2 but it was included because it was considered desirable to evaluate a diet containing a high level of fishmeal. Furthermore, because evaluations A and B were conducted with a 2-week interval between them, it was desirable to reevaluate 
the samples after 1 week of storage and for this, one drumstick from each bird was used in evaluation $\mathbf{C}$ and evaluation $\mathrm{D}$.

In evaluation E of study III, (table 3) the taste panel simultaneously compared meat from birds receiving diets 7 to 11 , containing maximum levels of either tuna fishmeal or meat meal with bone in combination with soybean

TaBLs 2.-Panel evaluation of meat from chickens fed diets containing different combinations of tuna, meat, and soybean meals in study $I I^{1}$

\begin{tabular}{|c|c|c|c|c|c|c|c|c|}
\hline \multirow[b]{2}{*}{ Score } & \multicolumn{4}{|c|}{ Evaluation C, 1} & \multicolumn{4}{|c|}{ Evaluation D, s } \\
\hline & $\begin{array}{l}\text { Diet 1 } \\
\text { (24-per- } \\
\text { cent soy- } \\
\text { bean) }\end{array}$ & $\begin{array}{c}\text { Diet } 2 \\
\text { (24-per- } \\
\text { cent tuns) }\end{array}$ & $\begin{array}{c}\text { Diet 3 } \\
\text { (12-per- } \\
\text { cent tuna } \\
+12-\text { per- } \\
\text { cent sog- } \\
\text { bean) }\end{array}$ & $\begin{array}{c}\text { Diet } 4 \\
\text { (12-per- } \\
\text { cent tung } \\
+12 \text {-per- } \\
\text { cent meat) }\end{array}$ & $\begin{array}{c}\text { Diet } 1 \\
\text { (24-per- } \\
\text { cent soy- } \\
\text { bean) }\end{array}$ & $\begin{array}{c}\text { Diet } 2 \\
\text { (24-per- } \\
\text { cent tuna) }\end{array}$ & $\begin{array}{c}\text { Diet 3 } \\
\text { (12-per- } \\
\text { cent tuna } \\
+ \text { 12-per- } \\
\text { cent goy- } \\
\text { bean) }\end{array}$ & $\begin{array}{c}\text { Diet } 4 \\
\text { (12-per- } \\
\text { cent tuna } \\
\text { + 12-per- } \\
\text { cent meat) }\end{array}$ \\
\hline $\begin{array}{l}\text { Total } \\
\text { Average }\end{array}$ & $\begin{array}{r}11.0 \\
+0.8\end{array}$ & $\begin{array}{r}10.0 \\
+0.7\end{array}$ & $\begin{array}{r}11.0 \\
+0.8\end{array}$ & $\begin{array}{r}12.0 \\
+0.9\end{array}$ & $\begin{array}{r}10.0 \\
+0.8\end{array}$ & $\begin{array}{r}12.5 \\
+1.0\end{array}$ & $\begin{array}{r}11.0 \\
+0.9\end{array}$ & $\begin{array}{r}9.0 \\
+0.8\end{array}$ \\
\hline
\end{tabular}

1 See 1 table 1.

Evaluation C conducted May 4, 1966.

- Range $(n=14)$ among totals for difference at $P<.05=9.6$ (N.S.).

- Evaluation D conducted May 10, 1966.

- Range $(n=12)$ among totals for difference at $\mathrm{P}<.05=9.5$ (N.S.).

TaBLe 3.-Panel evaluation of meat from chickens fed diets containing different combinations of tuna, meat, and soybean meals in study III'

\begin{tabular}{|c|c|c|c|c|c|}
\hline \multirow[b]{2}{*}{ Score } & \multicolumn{5}{|c|}{ Evaluation Es, 8} \\
\hline & $\begin{array}{c}\text { Diet y } \\
\text { (13.1-percent } \\
\text { soybean } \\
+ \text { 11.0-percent } \\
\text { tuna) }\end{array}$ & $\begin{array}{c}\text { Diet 8 } \\
\text { (13.4-percent } \\
\text { soybean +8.3- } \\
\text { percent tuana } \\
\text { 2.8-percent } \\
\text { meat) }\end{array}$ & $\begin{array}{c}\text { Diet 9 } \\
\text { (13.7-percent } \\
\text { soybean }+5.5- \\
\text { percent tuna } \\
+5.5 \text {-percent } \\
\text { meat })\end{array}$ & $\begin{array}{c}\text { Diet 10 } \\
\text { (13.9-percent } \\
\text { soybean }+2.8- \\
\text { percent tuna } \\
+8.3 \text {-percent } \\
\text { mest) }\end{array}$ & $\begin{array}{c}\text { Diet I1 } \\
\text { (14.2-percent } \\
\text { sogbean } \\
+ \text { 11.0-percent } \\
\text { meat) }\end{array}$ \\
\hline $\begin{array}{l}\text { Total } \\
\text { Average }\end{array}$ & $\begin{array}{r}12.5 \\
+1.0\end{array}$ & $\begin{array}{r}13.0 \\
+1.0\end{array}$ & $\begin{array}{r}13.5 \\
+1.1\end{array}$ & $\begin{array}{r}17.0 \\
+1.4\end{array}$ & $\begin{array}{r}14.0 \\
+1.2\end{array}$ \\
\hline
\end{tabular}

1 See 1 table 1.

2 Evaluation E conducted January 10, 1968.

- Range $(n=12)$ among totals for difference at $\mathrm{P}<.05=8.5$ (N.S.).

meal. None of these diets in evaluation $\mathbf{E}$ surpassed the 1 percent calcium tolerance of the birds; the contrary occurred with some diets in studies $\mathbf{A}$ to D. Calcium content exceeding 1 percent of the diet reportedly affects the growth performance of the broilers unfavorably (8).

Birds representative of the different treatments to be evaluated by the taste panels were slaughtered and frozen. The carcasses were transferred to 
a refrigerator for thawing the afternoon prior to the panel evaluation. In the morning of the evaluation, the drumsticks were properly cut, sprinkled with salt, wrapped in aluminum foil, and placed in an oven at $350^{\circ} \mathrm{F}$. $\left(160^{\circ} \mathrm{C}\right.$.) for $11 / 2$ hours. Once properly cooked, they were divided into small pieces, and grease that had been eliminated in the cooking process was spread over them. The samples placed under a red light, were offered at random to the panel members. Each panelist was provided with a glass of water to rinse out his mouth between evaluations. The statistical evaluation of all data was based on the method described by Krammer (6).

\section{RESULTS AND DISCUSSION}

The data of panel evaluations from studies I, II and III are presented in tables 1,2 and 3, respectively.

Samples of meat from birds from all six treatments of nutritional study I (table 1), compared at two different dates in evaluations A and B, were acceptable to the trained panel members, and no fishy or off flavors nor odors were reported. It is worth mentioning that the group having the highest acceptance-score was that of the birds receiving tuna fishmeal as the only protein source, evaluated on the first date. The meat from the group that received equal parts of tuna and meat meals had a marginal level of acceptability. This could have been caused by the additional storage of this meat in comparison with that evaluated on the first date.

To prevent any effects due to storage which occurred apparently in evaluations $A$ and $B$, simultaneous comparisons of all representative groups of study II were performed immediately after slaughter, and a week later, as evaluations $C$ and $D$, respectively (table 2). There were no statistical differences between the groups at evaluation $\mathrm{C}$. The average for the groups receiving diets 1 and 3 were identical to those obtained in evaluation $\mathbf{A}$. The group receiving diet $2 \mathrm{had}$ a lower score than evaluation $\mathrm{A}$ and that receiving diet 4 had a higher score than in evaluation $B$.

In evaluation D, the second "drumstick" of the birds utilized in evaluation $\mathbf{C}$ were compared a week after slaughter. The score remained about the same as in evaluation $\mathbf{C}$, and there were no statistical differences between the groups. The samples from the group that received diet 2 scored higher than in evaluation $\mathbf{C}$ and lower than in evaluation $\mathrm{A}$.

Two trends are worth mentioning in comparing the average scores of identical groups in the four evaluations. The group receiving diet 2 was scored at $+0.7,+1.0$, and +1.2 by the panel at 1 day, 1 week, and 2 weeks after slaughter, respectively. Correlative scores for the group receiving diet 4 were $+0.9,+0.8$, and +0.6 . Whereas there is a marked upward trend for the diet 2 values, there is a downward trend in the diet 4 scores. These observations merit further and more detailed investigations to 
determine the interrelations between protein combinations in the diet, time of storage of the meat of the birds reared on them, and the flavor score as determined by a trained panel.

The diet supplying 24-percent tuna fishmeal and 4.68-percent fat, supplied only 1.12 percent of fish oil. This level did not produce fishy or off flavor or odor in the meat, as demonstrated by the scores given to the compared samples. In all cases the palatability of the meat was repeatedly acceptable. These findings agree with the findings of Dansky (2), Edwards and May (S), Fry et al. (4), Hardin (5), and Sala and Chiarella (11), in which meal and oil from other species of fish were evaluated.

Practical-type broiler diets should not contain levels of calcium higher than 1 percent. Under these conditions tuna fishmeal should not be used at levels higher than 12 percent of the diet. This applies particularly in Puerto Rico, where tuna fishmeal samples analyzed in our laboratory consistently show a calcium content of approximately 8 percent, in contrast to approximately 5 percent reported elsewhere (10).

$\therefore$ The diets used in studies I and II were formulated using calculated values (8), which upon chemical analyses proved to have a higher calcium content than expected, and in some cases surpassed the calcium tolerance of 1 pereent of the diet of the birds. In nutritional study III (table 3), practical levels of fishmeal alone or in combinations with meat meal with bone were used in diets formulated not to exceed the tolerance.

-Meat samples representative of all groups in study III were evaluated simultaneously for flavor and odor by a trained panel. The averages reported are shown in table 3. As in the previous comparisons, there were no statistically significant differences; the palatability of the meat was acceptable, and no fishy or off flavors or odors were reported. This experiment demonistrates that, under practical conditions, the level of tuna fishmeal and/or meat meal with bone in the diet, which is limited by their calcium content if maximum growth performance is to be expected, will be determined by the protein unit cost as compared to that of soybean meal.

\section{SUMMARY}

Five trained panel evaluations were completed for flavor and odor of drumstick meat from broilers which received diets containing different combinations of tuna, meat, and soybean meals. Levels as high as 24-percent tuna fishmeal and/or meat meal with bone were compared.

There were no statistically significant differences $(P<.05)$ in the average scores of the panels for the different combinations evaluated. All had acceptable palatability scores and there were no reports of fishy, off flavor or odor.

Tuna fishmeal and/or meat meal with bone should not constitute more 
than 12 percent of practical-type diets for broilers, so as not to exceed the 1 percent calcium tolerance factor required for maximum growth performance. Based on the results obtained in study III, in which cạlcium levels werre within the tolerance range, the proportion of tuna fishmeal and/or meat meal with bone to be used should be based on the protein unit cost when compared to that of soybean meal.

Trends were observed in the increase and decrease in acceptability of the meat in relation to storage time. More detailed research is warranted in this area to determine the interrelationship of protein sources, length of time in storage, and flavor scores.

\section{RESUMEN}

En este estudio se hicieron cinco evaluaciones repecto al sabor y al olor de la carne de cadera de pollos para parrilla, que se sometieron a diversas dietas, a base de varias combinaciones de harina de atún, carne y soja. En las dietas se usaron niveles de hasta un 24 por ciento de harina de átún y/o de carne. Paneles entrenados efectuaron los catados.

No se encontraron diferencias estadisticamente significativas $(P<.05)$ entre los diversos tratamientos, en los diferentes catados que se llevaron a cabo. Todos fueron aceptables desde el punto de vista del sabor, y ninguno de los miembros de los paneles se percató de sabores o de olores indeseablesa marisco o de otra naturaleza-en la carne.

Las dietas prácticas para las aves destinadas al asado a la parrilla no deben contener más de un 12 por ciento de atún y/o de carne con hueso, para cumplir con la tolerancia máxima de 1 por ciento de calcio en la dieta, que es lo necesario para el crecimiento óptimo de las aves. Basado en los resultados obtenidos en el estudio III, donde los niveles de calcio estaban dentro de los requisitos de tolerancia, la proporción de harina de atún y/o de carne con hueso a usarse, debe depender del costo por unidad de la proteína, al compararse con el de la harina de soja.

Se observaron tendencias hacia un aumento y una disminución en cuanto a la aceptabilidad del sabor en el caso de aquellas porciones de carne que se sometieron a tratamientos en los cuales varió el tiempo del almacenamiento. Estos resultados justifican el que se lleve a cabo una investigación más detallada sobre las interrelaciones entre las fuentes de la proteina en las dietas, el período de almacenamiento y la aceptabilidad de la carne.

\section{LITERATURE CITED}

1. Carlson, D., Potter, L. M., Matterson, L. D., Singsen, E. P., Gilpin, G. L., Restrom, R. A., and Dawson, E. H. Palatability of chicken fed diets containing different levels of fish oil or tallow, II, Evaluation by a trained panel, Food Technol. 11: 615-20, 1957. 
2. Dansky, I. M., The growth promoting properties of menhaden fish oil as influenced by various fats, Poultry Sci. 41: 1352-4, 1962.

3. Edwards, Jr., H. M., and May, K. N., Studies with menhaden oil in practical type broiler rations, Poultry Sci. 44: 685-9, 1965.

4. Fry, J. L., Van Wallenhem, P., Waldroup, P. W., and Harms, R. H., Fish meal studies, 2, Effects of levels and sources on fishy flavor in broiler meat, Poultry Sci. 44: 1016-9, 1965.

5. Hardin, J. O., Milligan, J. L., and Sidwell, V. D., The influence of solvent extracted fish meal and stabilized fish oil in broiler rations on performance and on the flavor of broiler meat, Poultry Sci. 49: 858-60, 1964.

6. Kramer, A., and Ditman, L. P., A simplifed variables taste panel method for detecting flavor changes in vegetables treated with pesticides, Food Technol. 10: 155-9, 1956.

7. Leong, K. C., Knobl Jr., G. M., Snyder, D. G., and Gruger Jr., E. H., Feeding of fish oil and ethyl ester fractions of fish oil to broilers, Poultry Sci. 48: 123540, 1964.

8. Morassi, J. A., and Soldevila, M., Effects of different combinations of tuna fishmeal, meat meal with bone and soybean meal upon growth rate and utilization of feed by broilers in the starting and fattening periods, M.S. thesis of senior author, unpublished, 1966.

9. National Research Council, Nutrient requirements of domestic animals, Nutrient requirements of poultry, Publ. 1345, 1966.

10. National Research Council, Joint United States-Canadian Tables of Feed Composition, Publ. 1232, 1964.

11. Sala, J. C. and Chiarella, C., Effects of using varying quantities of anchovy meal (Engraulis ringens) on the flavor of chicken meat, Paper presented at the 4th Annual Conference of the International Association of Fishmeal Manufacturers, Lima, Perú, 1963. 